University of Nebraska - Lincoln

DigitalCommons@University of Nebraska - Lincoln

Entomology Papers from Other Sources

Entomology Collections, Miscellaneous

1998

\title{
Using Ant Species (Hymenoptera: Formicidae) as a Biological Indicator of Agroecosystem Condition
}

\author{
Steven L. Peck \\ Environmental Monitoring and Assessment Program-Agricultural Lands Resource Group, 1509 Varsity \\ Drive, Raleigh, NC 27608 \\ Betty Mcquaid \\ Environmental Monitoring and Assessment Program-Agricultural Lands Resource Group, 1509 Varsity \\ Drive, Raleigh, NC 27608 \\ C. Lee Campbell \\ Environmental Monitoring and Assessment Program-Agricultural Lands Resource Group, 1509 Varsity \\ Drive, Raleigh, NC 27608
}

Follow this and additional works at: https://digitalcommons.unl.edu/entomologyother

Part of the Entomology Commons

Peck, Steven L.; Mcquaid, Betty; and Campbell, C. Lee, "Using Ant Species (Hymenoptera: Formicidae) as a Biological Indicator of Agroecosystem Condition" (1998). Entomology Papers from Other Sources. 91. https://digitalcommons.unl.edu/entomologyother/91

This Article is brought to you for free and open access by the Entomology Collections, Miscellaneous at DigitalCommons@University of Nebraska - Lincoln. It has been accepted for inclusion in Entomology Papers from Other Sources by an authorized administrator of DigitalCommons@University of Nebraska - Lincoln. 


\title{
Using Ant Species (Hymenoptera: Formicidae) as a Biological Indicator of Agroecosystem Condition
}

\author{
STEVEN L. PECK, ${ }^{1,2}$ BETTY MCQUAID, ${ }^{1,3,4}$ AND C. LEE CAMPBELL ${ }^{1,2}$
}

\begin{abstract}
Environ. Entomol. 27(5): 1102-1110 (1998)
ABSTRACT Ant species assemblages have been used as biological indicators of environmental condition in many different ecosystems. To assess the potential of using ants as environmental indicators of agroecosystem condition, ants were collected from a stratified random sample of agricultural fields planted in annually harvested herbaceous crops at 90 sites in North Carolina and Virginia. The ants were identified to species and correlations with soil, management and crop variables were examined as the 1st step in developing an environmental indicator of agroecosystem condition. A total of 41 species of ants was found. Ant species assemblages were found to differ significantly between the fields and the field margin. Ant species assemblages were correlated with soil variables, tillage practices, and insecticide use, suggesting that ants have potential as a biological indicator of agroecosystem condition.
\end{abstract}

KEY WORDS ants, Formicidae, indicator species, agroecosystem condition, biological indicator

INSECTS HAVE BEEN used as indicators of a range of environmental attributes since the turn of the century (Cairns and Pratt 1993). In aquatic systems insects have enjoyed great success in monitoring pollution levels (Resh and McElravy 1993) and in indicating general water quality (Terrell and Perfetti 1989). Aquatic insects are arguably the most successfully applied group of bioindicators. Insects are thought to make good indicators because they respond quickly to environmental stress, have short generation times, and are usually easily sampled and identified. They also meet 3 of Noss's (1990) criteria for good biological indicators: they are sufficiently sensitive to provide an early warning for change, distributed over a wide geographical area, and capable of providing a continuous assessment over a wide range of stresses.

Despite the success of insects as bioindicators in aquatic systems, they have not enjoyed the same level of interest in terrestrial systems. However, many of the features that make insects useful as environmental indicators in aquatic systems carry over into terrestrial systems and there have been several successes in this area. Holloway and Stork (1991) used Lepidoptera as an indicator of change in habitats in South Africa. Kremen (1992) explored the use of butterflies as an indicator of the health of natural areas in Madagascar

\footnotetext{
This article reports the results of research only. Mention of a proprietary product does not constitute an endorsement or a recommendation by USDA for its use.

${ }^{1}$ Environmental Monitoring and Assessment Program-Agricultural Lands Resource Group, 1509 Varsity Drive, Raleigh, NC 27608.

${ }^{2}$ Department of Plant Pathology, North Carolina State University, Raleigh, NC 27695-7616.

${ }^{3}$ Department of Soil Science, North Carolina State University Raleigh, NC 27695-7616.

${ }^{4}$ National Resource Conservation Service, USDA, Raleigh, NC 27695-7616.
}

rain forests. Kromp (1990) used carabid beetles as a bioindicator of farm management in Austrian potato fields and Eyre et al. (1989) used carabids and curculionoids as indicators of grassland management practices. Kremen et al. (1993) argued that terrestrial arthropod assemblages could be used in assessing biodiversity for conservation planning, management, and reserve design. Samways (1996) used spatial patterns of adult dragonflies as indicators of changes in microhabitat for planning conservation ponds. Williams (1993) has used terrestrial arthropods to explore how effective restoration of wetland forests have been in efforts to restore sites to their original condition after human perturbations.

One success in using insect indicators in terrestrial ecosystems is that of ants in mine site reclamation in Australia (Majer 1985, 1996; Andersen 1993) and in Brazil (Majer 1994) and as an indicator of habitat quality in Australian conservation parks (Yeatman and Greenslade 1980). Ant species also effectively track environmental gradients (Petal et al. 1975, Lynch 1981, Levings 1983, Andersen 1986, Lynch et al. 1988, Heatwole 1989, Majer and Camer-Pesci 1991, Andersen 1993). This has been found to be true in agroecosystems. Roth et al. (1994) looked at the effects of crop management on ant diversity in Costa Rica as did Perfecto (1990) in Nicaragua and both found associations between ant diversity and vegetative structure and other components of crop management. Lobry De Bruyn (1993) found that certain ant assemblages indicated soil type in farmland and naturally vegetated areas. Delabie and Fowler (1993) found temporal correlations with several environmental factors for ants in Brazilian cocoa plantations. Tian et al. (1993) found ant populations were related to the nitrogen content of plant residues placed on soil sur-

0046-225X/98/1102-1110\$02.00/0 (C) 1998 Entomological Society of America

This article is a U.S. government work, and is not subject to copyright in the United States. 


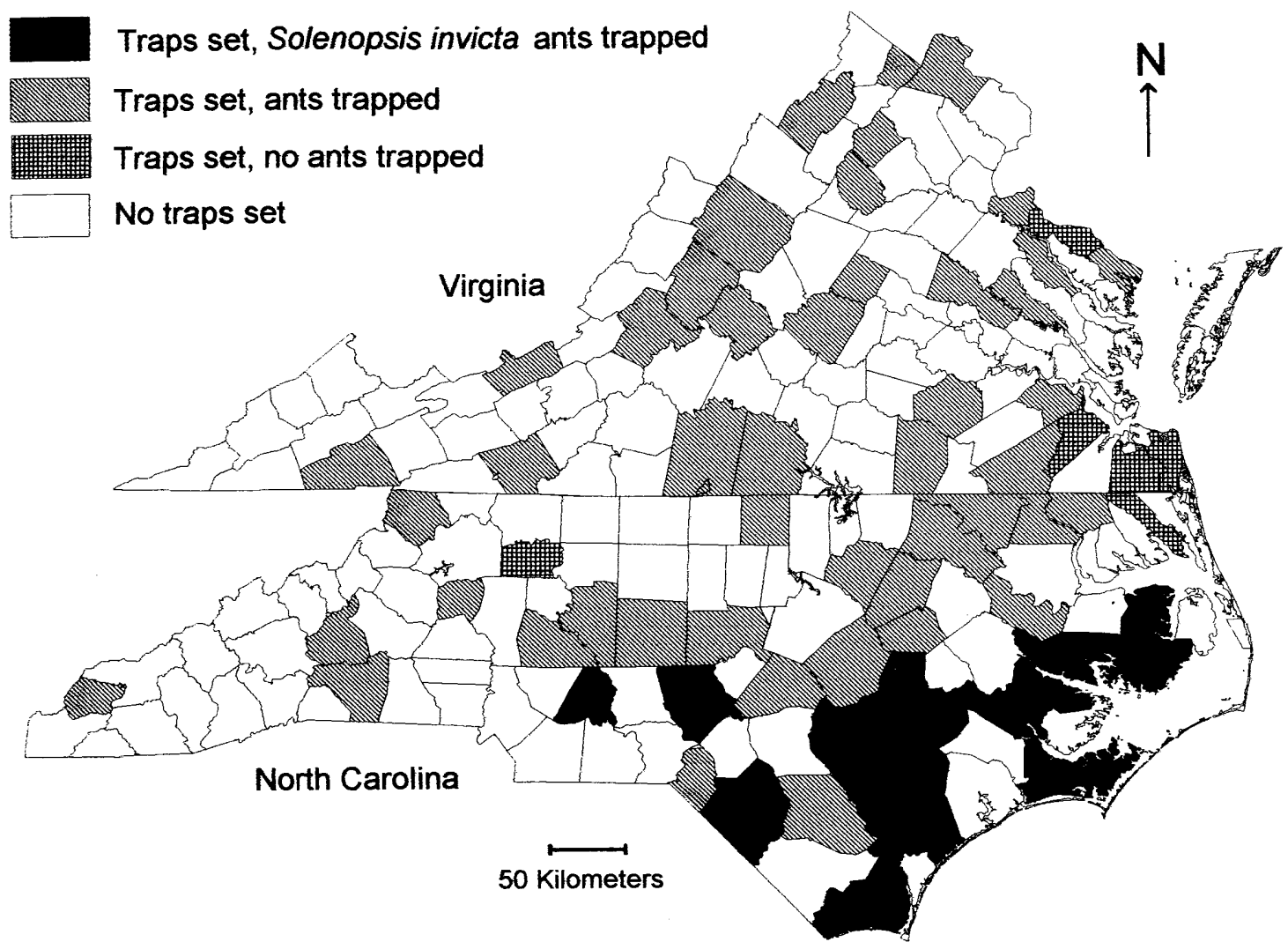

Fig. 1. Counties in Virginia and North Carolina where sample fields were selected for ant sampling. Actual locations are not available because of National Agriculture Statistics Service confidentiality restrictions.

faces to retain moisture and increase heat in tropical agroecosystems. Samways (1981) found a greater number of ant species in citrus orchards that were under biological control than those where California red scale, Aonidiella aurantii (Maskell), was being controlled with insecticides. Our own experience with a small pilot study looking at differences in ant assemblages in organic, and conventionally managed farms and conservation-tilled and conventionally tilled farms showed significant differences in the ant species diversity found in each of the field types (S.L.P., unpublished data).

Previous studies suggest that ants may have potential as a biological indicator of soil condition and management for crop growth and ecosystem services in agroecosystems. To develop an indicator at least 2 factors are necessary. First, the organism or group of organisms must be sensitive to changes in the environment that one is interested in monitoring. Second, the response of the organism must be calibrated to known levels of change, so that changes in biological response can be connected to changes in the environment. In this study we explored only the 1st factor by asking, Do ant species assemblages reflect changes in the components of agroecosystem health? Specifically, we hypothesize that assemblages of ant species in the agroecosystem will show significant differences depending on management practices, soil condition, and chemical inputs.

\section{Materials and Methods}

Collection Methods. Ants were sampled at 90 locations in a randomly chosen subset of the USDA, National Agricultural Statistics Service (NASS) fall survey (Fig. 1) between 31 July 1995 and 12 August 1995. The NASS enumerators took all samples after being trained in a 2-d, hands-on workshop. The design of this survey is explained in detail in Cotter and Nealon (1987). In brief, agricultural fields planted with annually harvested herbaceous crops in North Carolina and Virginia were selected with probability proportional to size (in hectares) from a stratified, randomsampling design. Once the sampled field was located, and permission obtained from the grower to sample ants from his or her field, the field was drawn on a piece of paper. Because both the interior of fields and field margins were to be sampled, edges ineligible to be sampled were marked. Areas ineligible for sampling included, areas that were inaccessible because of dense vegetation, such as thorny bushes or other obstacles that would keep the enumerator from working in the area. Also field edges less than a meter from roads or water bodies were not sampled. Clearly vis- 
Pitfall Trap Positions

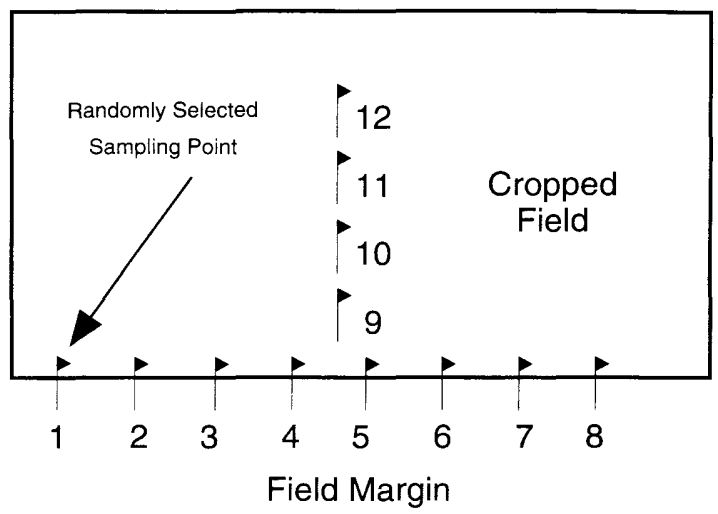

Fig. 2. Layout for placement of pitfall traps in the selected fields. Distance between traps was $7 \mathrm{~m}$. See text for details on pitfall sampling protocols.

ible mounds of the ant, Solenopsis invicta Buren, also made an area in the field ineligible for sampling due to the expected reduction in ant diversity (Mann 1994). A plastic game-spinner was then placed on the handdrawn map and spun repeatedly until it pointed to an area eligible for sampling.

At the selected area, the NASS enumerator placed a T-shaped transect (Fig. 2) of pitfall traps, with the top crossbar of the $T$ consisting of 8 traps laid in the field margin and the perpendicular stem of the $T$ consisting of 4 traps placed in the field. Traps were $7 \mathrm{~m}$ apart. In every 6 th field a replicate transect was placed in the field to assess the within-field component of variance.

The pitfall traps consisted of a 60 -ml Nalgene bottle with a $45-\mathrm{mm}$ opening, filled half way with a mixture of $25 \%$ glycerin, $60 \% \mathrm{EtOH}$, and $15 \%$ water. Traps were placed in holes dug carefully with a minimum of soil and vegetation disturbance such that the lip of the trap was even with the surface of the soil. The traps were left in place for $24 \mathrm{~h}$. If rain was predicted to last for $>8 \mathrm{~h}$, the sampling of that field was delayed. A rain cover was provided if any rain was predicted to fall during the $24 \mathrm{~h}$ period. Because this was a unique survey, and although it was not intended for this purpose originally, the location of counties where populations of $S$. invicta were found were noted.

The traps were collected and filled to capacity with 95\% EtOH to act as a preservative. Labels with field identifiers were placed inside and affixed outside the trap and the samples were shipped by Federal Express for taxonomic identification at the Agriculture Research Service (ARS) Jornada Experiments range in Las Cruces, New Mexico. Each ant was keyed to species.

At 2 of the trapping locations in each field margin, the density of vegetation was measured by inserting a marked $1.5-\mathrm{m}$ stick into the ground and recording the number of times (with a maximum 4 times) the stick was touched in areas on the stick between $0-5 \mathrm{~cm}$,
Table 1. Occurrence of ant species for various regions of fields

\begin{tabular}{c}
\hline Subfamily and species of ant \\
$\begin{array}{c}\text { \% fields where each ant } \\
\text { species was found by } \\
\text { various region, of fields }\end{array}$ \\
\cline { 2 - 2 } $\begin{array}{c}\text { Within Margins } \\
\text { cultivated (4 traps only) Both } \\
\text { portion }\end{array}$ \\
\hline
\end{tabular}

Sampled ant species found both in North Carolina and Virginia Dolichonderinae

$\begin{array}{llll}\text { Forelius pruinosus (Roger) } & 21 & 39(33) & 19\end{array}$

$\begin{array}{llll}\text { Tapinoma sessile (Sav) } & 4 & 19(13) & 2\end{array}$

Formicinae

$\begin{array}{llll}\text { Camponotus pennsylvanicus } & 0 & 7(6) & 0\end{array}$

(DeGeer)

Camponotus $\mathrm{Sp}$.

Formica argentea Wheeler

Formica pallidefulva Latreille

Formica schaufussi Mayr

Lasius alienus (Foester)

Lasius neoniger Emery

Lasius umbratus (Nylander)

Paratrechina faisonensis (Forel)

Paratrechina parcula (Mayr)

Prenolepis imparis (Say)

Myrmicinae

Aphaenogaster fulva Roger

Aphaenogaster rudis Emery

Aphaenogaster treatae Forel

Crematogaster lineolata (Sav)

Leptothorax pergandei Emery

Monomorium minimum (Buckley)

Myrmica americana Weber

Myrmica sp.

Pheidole bicarinata Forel

Pheidole dentata Mavr

Pheidole S1

Pheidole S2

Pheidole $\mathrm{S} 3$

Pheidole S4

Solenopsis texana Buren

Ponerinae

Ponera pennsylvanica Buckley

$9(6)$

$21(10)$

$14(11)$

12 (9)

$63(50)$

$11(6)$

2 (1)

$13(10)$

7 (2)

$6(2)$

3 (1)

$31(28)$

$10(8)$

$11(7)$

1 (1)

$42(31)$

11 (8)

7 (4)

$7(4)$
$59(44)$

$4(1)$

$17(9)$

$1(0)$

33 (24)

$12(10)$

$56(39)$

5 (4)

Sampled ant species located only in North Carolina

Dolichonderinae

$\begin{array}{llcl}\text { Conomyrma bureni Trager } & 8 & 13(10) & 7\end{array}$

$\begin{array}{llll}\text { Conomyrma medeis Trager } & 3 & 3(3) & 3\end{array}$

Formicinae

Brachymyrmex depilis Emery $\quad 1 \quad 1(1) \quad 0$

Formica Spl.

Myrmicinae

Crematogaster ashmeadi Mayr

Myrmica incompleta Provancher

Pheidole morrisi Forel

Solenopsis inticta Buren

Ponerinae

$\begin{array}{llll}\text { Brachyponera solitaria (F. Smith) } & 1 & 1(1) & 0\end{array}$

Sampled ant species located only in Virginia

Myrmicinae

$\begin{array}{llll}\text { Crematogaster cerasi (Fitch) } & 0 & 2(1) & 0\end{array}$

Tetramorium caespitum (L.)

$11(9)$

4

Percentages broken down into species found within cropped (i.e., cultivated) regions of field, in the field margin, or both. Because the margin had 8 traps compared with 4 in the cropping region, the numbers in parentheses indicate the percentage of fields with the given ant species based on the first 4 traps in the margin only-to adjust for the sample size differences between the 2 regions of the field.

$6-15 \mathrm{~cm}, 16-35 \mathrm{~cm}, 35-60 \mathrm{~cm}$, and $<60 \mathrm{~cm}$ above the surface. The type and height of the crop also was recorded. 
Table 2. Occurrence of ant species for various crops

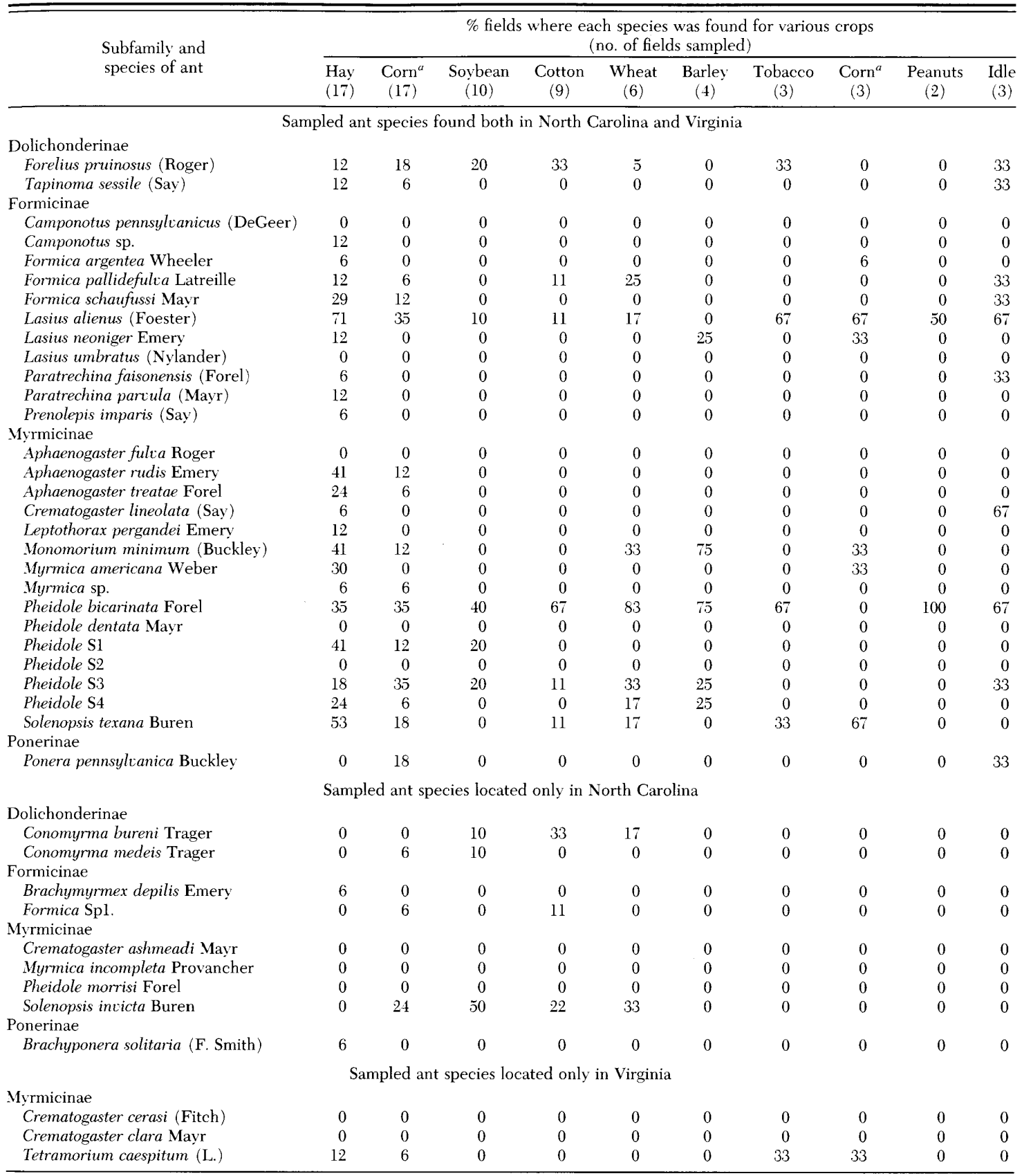

Data is based on sampling within the cropped portion of the field only and for crops where $>1$ sample field was included in the survey. Entries in table are percentages.

${ }^{a}$ Field corn.

In November 1995, the USDA-NASS enumerators returned to the selected field and the grower completed a questionnaire on cropping history, pesticide use, fertilizer use, tillage, integrated pest management, and irrigation. At that time extensive soil sampling was conducted, as explained in detail in Schumacher $(1994 \mathrm{a}, \mathrm{b})$. Tillage was divided into 2 categories: conservation tillage (which included notill, strip-till, ridge-till, and mulch-till) and conventional tillage.

Statistical Methods. Because traps were placed $7 \mathrm{~m}$ apart, we assumed for some analyses that the traps were far enough apart that the catches in different traps were from different colonies of ants. 
Table 3. The number of fields sampled and the median number of ant species found in each crop type

\begin{tabular}{lcc}
\hline \hline \multicolumn{1}{c}{ Crop } & $\begin{array}{c}\text { No. fields } \\
\text { sampled }\end{array}$ & $\begin{array}{c}\text { Median no. } \\
\text { ant species } \\
\text { (25th, } 75 \text { th percentile) }\end{array}$ \\
\hline Non-alfalfa hay & 17 & $4(4,6)$ \\
Field corn & 17 & $2(1,5)$ \\
Soybeans & 10 & $1.5(1,3)$ \\
Cotton & 9 & $2(1,3)$ \\
Wheat & 6 & $3(2,4)$ \\
Barley & 4 & $2.5(2,3.5)$ \\
Tobacco & 3 & $3(0,3)$ \\
Corn-silage & 3 & $3(1,6)$ \\
Peanuts & 2 & $1.5(1,2)$ \\
\hline
\end{tabular}

${ }^{a}$ Ant species found with the cultivated region of the field.

Nonparametric median tests of species richness between traps in the field and those in the field margins were done after adjusting for the larger sample size by using only 4 traps from the field margin (Dixon and Massey 1951). Mixed model analysis of variance (ANOVA), which uses both fixed and random effects, was used to explore the variance components of species richness within the trapping location (field or margin), within the cropped region of the field, and between states. The field was considered the basic sampling unit on which the data were taken. Because this study was not an experiment with randomized treatments, the ANOVA is interpreted in that light.

Species richness and diversity alone tend to obscure much of the community structure (Schluter and Ricklefs 1993); thus, using methods that retain information about the species assemblage itself is important. Furthermore, looking for multivariate relationships among processes of extremely high dimension, such as management practices, soil variables, and plant structure, is best approached through statistical procedures that reduce the dimensionality of the data. To explore these relationships, a species-field matrix was constructed such that the rows of the matrix indicate the field and the columns of the matrix represent number of times that a species was found in the field. The entries into the matrix were the number of pitfall traps in which each particular species (column) were found in a given field (row). To reduce the dimensionality, the principal components were obtained (Johnson and Wichern 1982). The eigenvectors of the principal components that explained $50 \%$ of the total variance were then used in general linear models (GLM) (logistic and least squares) to look for relationships among the ant data and the soil and management variables. For example, to determine if ant species were tracking tillage, the first 6 eigenvectors from the species matrix were used as independent predictors of conservation versus conventional tillage in a logistic model. Conversely, to see if the ant communities were being structured by soil variables, each of the eigenvectors was used as the dependent variable in a model containing the soil variables. Switching back and forth between ant species being a predictor and a dependent variable is consistent with the goal of looking for relationships that are correlative in nature. SAS sta- tistical software was used for all analyses (SAS Institute 1997).

\section{Results and Discussion}

Forty-one species of ants were found in the agroecosystems of North Carolina and Virginia (Table 1). S. invicta were found in 16 counties in North Carolina (Fig. 1).

There were significant differences found between the cultivated portion of a field and the field margin. In the cultivated portion of the field the median number of ant species sampled was 3 (quartiles [1, 4], range $[0,17])$. However, in the field margins the median number of species found in 4 adjacent traps (to adjust for sample-size differences between margin and cultivated portion sampling) was 4 (quartiles [3, $6]$, range $[0,13])$. These medians are significantly different $(P=0.001)$. The most common species in the cropped part of the fields was Pheidole bicarinata Forel, which was found in $42 \%$ of the cropped part of the fields and 59\% of the margins. Lasius alienus (Foester) was found in $33 \%$ of the cropped fields; this species also was found in $63 \%$ of the margins. S. invicta, an imported species of fire ant, was found more frequently in the field than in the field margin (18 versus $14 \%$ of the sampled fields, respectively), most other species were found preferentially in the field margins rather than the cultivated portion. This is not unexpected as the cultivated portion is generally more disturbed due to crop management, tillage, and insecticide use than is the field margin.

The median numbers of species per field found in each crop (in the cultivated portion of the selected field only) were different from one another $(P=$ 0.03 ), as tested with the nonparametric Median test. The greatest diversity of ants was found (Table 2 ) in non-alfalfa hay (a total of 26 species of ants in the 2 states, with a median of 4 species of ants per field), followed by field corn with 18 species in the 2 states, with a median of 2 species of ants per field. Lasius alienus (Foester), Forelius purinous (Roger), Monomorium minumum (Buckley), Solenopsis texana Emery, and Phiedole bicarninata Forel seemed best able to inhabit the widest variety of crop types, or were at least more common regardless of field type. It may be that these species are better colonizers and can more quickly adapt to the management regime imposed on cropping fields. Despite there being a greater number of ant species on a regional basis in these 2 crops, the median number of ant species found on a per-field basis did not vary extensively (Table 3 ). This may be because ants colonies are over dispersed (Bernstein and Gobbel 1979) and given the sampling distances between pitfall traps the numbers of species found in a transect were fairly constant.

The differences in conservation tillage and conventional tillage were striking (Table 4). In those species that were found in $>5 \%$ of the cropped fields (Table 1), 13 out of 17 species were more common in fields where conservation tillage was practiced than in fields where conventional tillage was used. For example, $M$. 
Table 4. Occurrence of ant species for various regions of fields managed with conservation tillage versus conventional tillage

\begin{tabular}{|c|c|c|c|c|}
\hline \multirow{2}{*}{$\begin{array}{l}\text { Subfamily and } \\
\text { species of ant }\end{array}$} & \multicolumn{4}{|c|}{$\%$ fields where each ant species was found by location and tillage } \\
\hline & $\begin{array}{c}\text { Conservation } \\
\text { tillage }\end{array}$ & $\begin{array}{c}\text { Conventional } \\
\text { tillage }\end{array}$ & $\begin{array}{c}\text { Conservation } \\
\text { tillage }\end{array}$ & $\begin{array}{c}\text { Conventional } \\
\text { tillage }\end{array}$ \\
\hline \multicolumn{5}{|c|}{ Sampled ant species found both in North Carolina and Virginia } \\
\hline \multicolumn{5}{|l|}{ Dolichonderinae } \\
\hline \multicolumn{5}{|l|}{ Formicinae } \\
\hline Camponotus pennsylvanicus (DeGeer) & 0 & 0 & 6 & 4 \\
\hline Camponotus Sp. & 6 & 2 & 9 & 6 \\
\hline Formica argentea Wheeler & 0 & 6 & 38 & 10 \\
\hline Formica pallidefulva Latreille & 16 & 2 & 16 & 16 \\
\hline Formica schaufussi Mayr & 19 & 4 & 19 & 6 \\
\hline Lasius alienus (Foester) & 48 & 28 & 71 & $\tilde{59}$ \\
\hline Prenolepis imparis (Say) & 0 & 2 & 6 & 2 \\
\hline \multicolumn{5}{|l|}{ Myrmicinae } \\
\hline Aphaenogaster fulva Roger & 0 & 0 & 6 & 2 \\
\hline Aphaenogaster rudis Emery & 23 & 4 & 56 & 12 \\
\hline Aphaenogaster treatae Forel & 12 & 2 & 21 & 0 \\
\hline Crematogaster lineolata (Say) & 6 & 2 & 9 & 10 \\
\hline Leptothorax pergandei Emery & 3 & 2 & 0 & 2 \\
\hline Monomorium minimum (Buckley) & 41 & 8 & 59 & 33 \\
\hline Myrmica americana Weber & 13 & 4 & 18 & 6 \\
\hline Myrmica Sp. & 3 & 2 & 12 & 2 \\
\hline Pheidole bicarinata Forel & 38 & 53 & 50 & 65 \\
\hline Pheidole dentata Mayr & 0 & 0 & 3 & 2 \\
\hline \multicolumn{5}{|l|}{ Dolichonderinae } \\
\hline Conomyrma bureni Trager & 0 & 10 & 3 & 18 \\
\hline Conomyrma medeis Trager & 0 & 6 & 0 & 6 \\
\hline \multicolumn{5}{|l|}{ Formicinae } \\
\hline Brachymyrmex depilis Emery & 0 & 2 & 3 & 0 \\
\hline Formica Spl. & 0 & 4 & 0 & 4 \\
\hline \multicolumn{5}{|l|}{ Myrmicinae } \\
\hline Crematogaster ashmeadi Mayr & 0 & 0 & 0 & 2 \\
\hline Myrmica incompleta Provancher & 0 & 0 & 0 & 2 \\
\hline Pheidole morrisi Forel & 0 & 0 & 0 & 4 \\
\hline Solenopsis invicta Buren & 6 & 29 & 9 & 27 \\
\hline \multicolumn{5}{|l|}{ Ponerinae } \\
\hline Brachyponera solitaria (F. Smith) & 0 & 2 & 3 & 0 \\
\hline \multicolumn{5}{|c|}{ Sampled ant species located only in Virginia } \\
\hline \multicolumn{5}{|l|}{ Myrmicinae } \\
\hline Crematogaster cerasi (Fitch) & 0 & 0 & 6 & 0 \\
\hline Crematogaster clara Mayr & 0 & 0 & 0 & 2 \\
\hline Tetramorium caespitum (L.) & 13 & 2 & 13 & 6 \\
\hline
\end{tabular}

The percentages are broken into species found within cropped region of field versus in the field margin. There were 4 pitfall traps in the cropped portion of the field and 8 traps in the margin. A total of 81 fields was sampled; 32 of these fields were managed with conservation tillage and 49 fields were managed with conventional tillage.

minimum was found in $41 \%$ of the cropped region of conservation-tilled fields compared with $8 \%$ of the conventionally tilled fields. The exceptions, where the species were more common in conventionally tilled fields, were species in disturbed environments such as S. invicta and Pheidole bicarinata Forel. These same patterns were observed in the field margins as well, presumably where tillage does not take place. Out of the 27 species that were found in at least $5 \%$ of fields (Table 1), 22 were found more abundantly in fields where conservation tillage was used. Conservation tillage may allow more stability in nesting sites, allowing interactions with other species to structure the community, rather than disturbance from farm man- 
Table 5. Results from mixed model analysis of variance on species richness of ants

\begin{tabular}{lcccr}
\hline \hline \multicolumn{1}{c}{ Effect } & Estimate $^{a}$ & $\mathrm{df}^{b}$ & $Z^{a}$ or $F^{b}$ & \multicolumn{1}{c}{$P$} \\
\hline \multicolumn{5}{c}{ Components of variance for random effects } \\
Field & 0.069 & - & 4.05 & $<0.001$ \\
Transect & 0.012 & - & 0.64 & 0.520 \\
Residual (traps) & 0.192 & - & 20.76 & $<0.001$ \\
\multicolumn{5}{c}{ The tests for fixed effects } \\
State & - & 1 & 10.4 & \\
Crop & - & 16 & 1.5 & 0.013 \\
Margin & - & 1 & 20.6 & $<0.001$ \\
Vegetation density & - & 12 & 1.4 & 0.147 \\
\hline
\end{tabular}

Variance components of the ants sampling testing the mixed model field, replication transect within field, and individual traps as subsamples within a transect were all random effects. State (NC, VA) crop, vegetation density, and field margin were all considered to be fixed effects.

${ }^{a}$ Estimate and $Z$ apply to random effects.

${ }^{b}$ Degrees of freedom and $F$ apply to fixed effects.

agement. That the influence of tillage is felt in the margin indicates that disturbances of this type may have effects beyond the boundaries of the disturbed area.

The between-transect component of variance was not significant $(P=0.520$, Table 5$)$, as would be expected. Significant differences in the number of ants species were found between the 2 states $(P=0.013)$ and between the cropped region of the field and the field margin $(P<0.001)$. Differences in the density of vegetation in the field margin were not significant $(P=0.147)$.

When the first 6 eigenvectors of the species-field matrix were regressed on tillage (conservation tillage $[n=39]$ versus conventional tillage $[n=55])$ in a logistic model, the model likelihood chi-square was $18.4(\mathrm{df}=6, P=0.005$ ) and the second principal component was a significant predictor $(P=0.003)$ for the ants in the field. For the ants in the field margin, the model likelihood chi-square was 22.7 ( $\mathrm{df}=6, P=$ 0.001 ) and the first principal component was significant at $P<0.001$. When the first 6 eigenvectors of the species-field matrix were regressed on a dichotomous variable indicating whether insecticides were used $(n=57)$, or not $(n=43)$ the model likelihood chisquare was $29.1(\mathrm{df}=6, P<0.001)$ within the field and 28.9 ( df $=6, P<0.001$ ) within the field margin, and the first principal component was significant $(P<$ $0.001)$. Within the field none of the principal components were significant predictors of insecticide use at the $P=0.05$ level; however, in the field margin the first principal component was a significant predictor of insecticide use $(P<0.001)$. Because insecticide use and conventional tillage were not independent $\left(\chi_{1}{ }^{2}=\right.$ $12.3, P<0.001)$ the same eigenvectors were predictive of both insecticide use and conventional tillage. The loadings on these 2 eigenvectors suggested that the following species assemblage may be an indicator of tillage and insecticide use in the field margin: Brachymyrmex depilis Emery, Paratrechina faisonensis (Forel), Prenolepis imparis (Say), Aphaenogaster trea-
Table 6. Wilks lambda statistic for testing the hypotheses that the given soil variable has no overall effect on the principal components of the species assemblage matrix

\begin{tabular}{lcccr}
\hline \multicolumn{1}{c}{ Soil variable } & Wilkes $\lambda$ & df & $F$ & \multicolumn{1}{c}{$P$} \\
\hline Cation exchange capacity & 0.74 & 6 & 4.45 & 0.001 \\
Base saturation & 0.88 & 6 & 1.80 & 0.110 \\
Electrical connectivity & 0.81 & 6 & 3.03 & 0.128 \\
Organic carbon & 0.81 & 6 & 1.71 & 0.010 \\
Nitrogen & 0.65 & 6 & 6.97 & $<0.001$ \\
PH & 0.84 & 6 & 2.43 & 0.033 \\
Sand & 0.78 & 6 & 3.61 & 0.003 \\
Clay & 0.73 & 6 & 4.65 & $<0.001$ \\
Soil moisture & 0.77 & 6 & 3.97 & 0.002 \\
\hline
\end{tabular}

Based on their loadings in the principal component found to predict tillage.

tae Forel, Leptothorax prergandei Emory, and Pheidole Sp1.

The Wilks lambda statistic was used to test the hypothesis that a given soil variable had no overall effect on the first 6 principal component vectors from the ant assemblage matrix (Table 6). We found that ant species assemblages were significantly correlated to certain soil variables. Indeed, only base saturation $(P=0.110)$ and electrical connectivity $(P=0.128)$ were not predictors of the ant species assemblage.

These results suggest that ants have potential as an environmental indicator in agroecosystems. Ant species assemblage was related to management factors, soil variables, and cropping practices. This study cannot fully establish ant assemblages as an indicator because all relationships explored through this survey are correlative in nature only. To use ants as an environmental indicator, species assemblages will have to be calibrated to known levels of disturbances that can affect agroecosystem conditions. However, this is a first step in indicator development and provides evidence that ants may be a good place to start in exploring biological indicators for agroecosystems. For example, The Environmental Protection Agency's Environmental Monitoring and Assessment Program was interested in developing environmental indicators for several ecological systems (Heck et al. 1991, Hunsaker and Carpenter 1990). Because they are ubiquitous in agroecosystems, easily sampled, taxonomically well understood, and as demonstrated in this survey, correlated with soil, cropping, and management variables, ants may be the best place to start for the development of a terrestrial indicator in agroecosystems. In addition, many of the attributes of ants that make them useful as a potential indicator in agroecosystems, may make them useful in other systemsthere are few ecological systems where ants are not present. We hope that this 1st step in developing ants as an indicator may spur further work and interest in developing this family of insects as a terrestrial indicator of environmental condition.

\section{Acknowledgments}

We thank Walt Whitford and Justin Van Zee (USDA- ARS Jornada Experiments range in Las Cruces, NM) for ant iden- 
tification to species. We thank Sarah Hoffman and Craig Hayes (USDA-NASS) without whose help this project would not have been possible. Special thanks to Osama Anas (North Carolina State University [NCSU]), Svenja Belaoussoff (University of Guelph), Robert Bugg (University of California-Davis), Harold Heatwole (NCSU), Deborah Letourneou (University of California-Santa Cruz), and Kathy Williams (San Diego State University), who attended a 2-d workshop on terrestrial indicators and provided many insights into developing biological indicators. We thank Walt Heck (NCSU), Steve Shafer (USDA-ARS), Sue Franson (EPA), and Jeff Bay, Dan Fiscus, Charles Harper, Anne Hellkamp, George Hess, Mike Munster, Deb Neher, and Gail Olson (all NCSU) for many insightful discussions during our EMAP years about environmental indicators. Comments from 2 reviewers also improved this article. Paul Barr (USDA-ARS) helped with the graphics. We acknowledge the excellent work of the USDA-NASS enumerators who collected the data for this study. This study was funded wholly or in part by the U.S. Environmental Protection Agency interagency agreement DW 1234170 to the USDA, Agricultural Research Service. The work also was supported in part through a Specific Cooperative Agreement (58-66452-016) between the USDA, Agricultural Research Service, and the North Carolina Agricultural Research Service.

\section{References Cited}

Andersen, A. N. 1986. Diversity, seasonality and community organization of ants at adjacent heath and woodland sites in south-eastern Australia. Aust. J. Zool. 34: 53-64.

1993. Ants as indicators of restoration success at a uranium mine in tropical Australia. Restoration Ecol. 1: 156-167.

Bernstein, R. A., and M. Gobbel. 1979. Partitioning of space in communities of ants. J. Anim. Ecol. 48: 931-942.

Cairns, J., and J. R. Pratt. 1993. A history of biological monitoring using benthic macroinvertebrates, pp. 10-27. In D. M. Rosenberg and V. H. Resh [eds.], Freshwater biomonitoring and benthic macroinvertebrates. Chapman \& Hall. New York

Cotter, J., and J. Nealon. 1987. Area frame design for agricultural surveys. Area Frame Section, Research and Applications Division, National Agricultural Statistics Service. USDA, Washington, D.C.

Delabie, J.H.C., and H. G. Fowler. 1993. Physical and biotic correlates of population fluctuations of dominant soil and litter ant species (Hymenoptera: Formicidae) in Brazilian cocoa plantations. J. N.Y. Entomol. Soc. 101: 135-140.

Dixon, W. J., and F. J. Massey, Jr. 1951. Introduction to statistical analysis. McGraw-Hill. New York..

Eyre, M. D., M. L. Luff, S. P. Rushton, and C. J. Topping. 1989. Ground beetles and weevils (Carabidae and Curculionoidia) as indicators of grassland management practices. J. Appl. Entomol. 107: 508-517.

Heatwole, H. 1989. Changes in ant assemblages across an Arctic treeline. Revue D'Entomologie Du Quebec. 34: $10-22$.

Heck, W. W., C. L. Campbell, R. P. Breckenridge, G. E. Byers, A. L. Finkner, G. R. Hess, J. R. Meyer, T. J. Moser, S. L. Peck, J. O. Rawlings, and C. N. Smith. 1991. Environmental monitoring and assessment program, agroecosystem monitoring and research strategy. EPA 600/4-91/ 013. Environmental Protection Agency. Washington D.C.

Holloway, J. D., and N. E. Stork 1991. The dimensions of biodiversity: the use of invertebrates as indicators of human impact, pp. 37-61. In D. L. Hawksworth [ed.], The Biodiversity of Microorganisms and Invertebrates: Its role in sustainable agriculture. $\mathrm{CAB}$ International. Wallingford, UK.

Hunsaker, C. T., and D. E. Carpenter. 1990. Environmental monitoring and assessment program: ecological indicators. EPA $/ 600 / 3-90 / 060$, Environmental Protection Agency. Washington D.C

Johnson, R. A., and D. W. Wichern. 1982. Applied multivariate statistical analysis. Prentice Hall, Englewood Cliffs, NJ.

Kremen, C. 1992. Assessing the indicator properties of species assemblages for natural areas monitoring. Ecol. Appl. 2: 203-217.

Kremen, C., R. K. Colwell, T. L. Erwin, D. D. Murphy, R. F. Noss, and M. A. Sanjayan. 1993. Terrestrial arthropod assemblages: their use in conservation planning. Conserv. Biol. 7: 796-808.

Kromp, B. 1990. Carabid beetles (Coleoptera, Carabidae) as bioindicators in biological and conventional farming in Austrian potato fields. Biol. Fert. Soils 9: 182-187.

Levings, S. C. 1983. Seasonal, annual, and among-site variation in the ground ant community of a deciduous tropical forest: some causes of patchy species distributions. Ecol. Monogr. 53: 435-455.

Lobry de Bruyn, L. A. 1993. Ant composition and activity in naturally vegetated and farmland environments on contrasting soils at Kellerberrin, Western Australia. Soil Biol. Biochem. 25: 1043-1056.

Lynch, J. F. 1981. Seasonal, successional, and vertical segregation in a Maryland ant community. Okios. 37: 183198.

Lynch, J. F., A. K. Johnson, and E. C. Balinsky. 1988. Spatial and temporal variation in the abundance and diversity of ants (Hymenoptera: Formicidae) in the soil and litter layers of a Maryland forest. Am. Mid. Nat. 119: 31-44.

Majer, J. D. 1985. Recolonization by ants of rehabilitated mineral sand mines on North Stradbroke Is. Queensland, with particular reference to seed removal. Aust. J. Ecol. 10: $31-48$

1994. Arboreal ant community patterns in Brazilian Farms. Biotropica 26: 73-83.

1996. Ant recolonization of rehabilitated bauxite mines at Trombetas, Para, Brazil. J. Trop. Ecol. 12: 257-273.

Majer, J. D., and P. Camer-Pesci. 1991. Ant species in tropical Australian tree crops and native ecosystems-is there a mosaic? Biotropica 23: 173-181.

Mann, C. C. 1994. Fire ants parlay their queens into a threat to biodiversity. Science (Wash. D.C.) 263: 1560-1561.

Noss, R. F. 1990. Indicators for monitoring biodiversity: a hierarchical approach. Conserv. Biol. 4: 355-364.

Perfecto, I. 1990. Indirect and direct effects in a tropical agroecosystem: The maize-pest-ant system in Nicaragua. Ecology 7: 2125-2134.

Petal, J., H. Jakubczyk, K. Chmielewski, and A. Tatur. 1975. Response of ants to environment pollution, pp. 363-373. Progress in soil zoology: proceedings of the international colloquium on soil zoology, 1973.

Resh, V. H., and E. P. McElravy. 1993. Contemporary quantitative approaches to biomonitoring using benthic macroinvertebrates, pp. 159-194. In D. M. Rosenberg and V. H. Resh [eds.], Freshwater biomonitoring and benthic macroinvertebrates. Chapman \& Hall, New York

Roth, D. S., I. Perfecto, and B. Rathcke. 1994. The effects of management systems on ground-foraging ant diversity in Costa Rica. Ecol. Appl. 4: 423-436.

Samways, M. J. 1981. Comparison of ant community structure (Hymenoptera: Formicidae) in citrus orchards under chemical and biological control of red scale, 
Aonidiella aurantii (Maskell) (Hemiptera: Diapididae). Bull. Entomol. 71: 663-670.

1996. Spatial patterns of dragonflies (Odonata) as indicators for design of a conservation pond. Odonatologica 25: 157-166.

SAS Institute. 1997. SAS/STAT user's guide, v. 6.1. SAS Institute, Cary, NC.

Schluter D., and R. E. Ricklefs. 1993. Species diversity: an introduction to the problem, pp. 1-10. In R. R. Ricklefs and D. Schluter [eds.], Species diversity in ecological communities. Chicago University Press, IL.

Schumacher, B. A. 1994a. EMAP Agricultural Lands 1994 Quality Assurance Project Plan: Mid-Atlantic Assessment Program. U.S. EPA. 620/.-94/002.

1994b. EMAP Agricultural Lands Quality Assurance Project Plan: 1994 Piedmont Fall Project. US. EPA 62/x94/xxx October 1994.
Terrell, C. R., and P. B. Perfetti. 1989. Water Quality indicators guide: surface waters. U.S. Dep. Agric. Soil Conserv. Serv. SCS-TP-161.

Tian, G., L. Brussaard, and B. T. Kang. 1993. Biological effects of plant residues with contrasting chemical compositions under humid tropical conditions: effects on soil fauna. Soil Biol. Biochem. 25: 731-737.

Williams, K. S. 1993. Use of terrestrial arthropods to evaluate restored riparian woodlands. Restoration Ecol. June: $107-116$.

Yeatman, E. M., and P.J.M. Greenslade. 1980. Ants as indicators of habitat in three conservation parks in south Australia. South Aust. Nat. 55: 20-26.

Received for publication 4 September 1997; accepted 29 May 1998. 